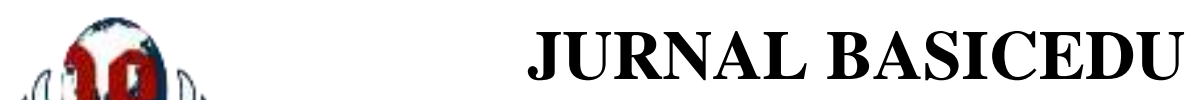

Volume 5 Nomor 6 Tahun 2021 Halaman 5204 - 5212

Research \& Learning in Elementary Education

https://jbasic.org/index.php/basicedu

\title{
Peningkatan Kemampuan Berliterasi melalui Model Discovery Learning Berbantuan Media Pohon Literasi
}

\author{
Maria Ulfa $^{1 凶}$, Eva Oktaviana $^{2}$ \\ STKIP Kusuma Negara, Indonesia ${ }^{1,2}$ \\ E-mail: mariaulfa@stkipkusumanegara.ac.id ${ }^{1}, \underline{\text { eva_oktaviana@ } \text { stkipkusumanegara.ac.id }^{2}}$
}

\begin{abstract}
Abstrak
Tidak ada waktu dan bahan bacaan yang dimiliki menjadi alasan untuk tidak membaca. Seharusnya, untuk mengikuti pembelajaran dan memecahkan masalah memerlukan kemampuan berliterasi dan itu diawali dari kebiasaan membaca. Penerapan model pembelajaran dan pemupukan kebiasaan membaca haruslah diterapkan pada setiap proses pembelajaran. Tujuan penelitian ini adalah untuk meningkatkan kemampuan berlitersi melalui model discovery learning berbantuan media pohon literasi. Penelitian ini merupakan action reseacrh classroom yang dilaksanakan selama 2 siklus. Subyek dari penelitian ini adalah siswa mahasiswa semester 6 Prodi PGSD, STKIP Kusuma Negara Tahun Ajaran 2021/2022 yang berjumlah 60 mahasiswa. Teknik pengumpulan data yang digunakan yaitu observasi, wawancara, tes, dan analisis dokumen. Validitas data menggunakan triangulasi teknik, sumber dan teknik validitas isi. Hasil penelitian menunjukkan bahwa penerapan model discovery learning berbantuan media pohon literasi dapat meningkatkan keterampilan berliterasi mahasiswa semester 6 Prodi PGSD, STKIP Kusuma Negara Tahun Ajaran 2021/2022.
\end{abstract}

Kata Kunci: Kemampuan Berliterasi, Media Pohon Literasi, Model Discovery Learning.

Abstract

There is no time and reading material that is owned is an excuse not to read. In fact, following learning and solving problems requires literacy skills and it starts with reading habits. The application of learning models and cultivating reading habits must be applied to every learning process. This study aims to improve capabilities in literature through a discovery learning model assisted by literature tree media. This research is an action research classroom that was carried out for 2 cycles. The subjects of this study were the 6th-semester students of the PGSD Study Program, STKIP Kusuma for the 2021/2022 Academic Year, totaling 60 students. Data collection techniques used are observation, interviews, tests, and document analysis. The validity of the data used triangulation techniques, sources, and content validity techniques. The results showed that the application of the discovery learning model assisted by the media literacy tree could improve the literacy skills of 6thsemester students of the PGSD Study Program, STKIP Kusuma Negara for the Academic Year 2021/2022.

Keywords: Capabilities in Literature, Literature Tree Media, Discovery Learning Model.

Copyright (c) 2021 Maria Ulfa, Eva Oktaviana

Corresponding author :

Email : mariaulfa@stkipkusumanegara.ac.id

DOI $\quad$ : https://doi.org/10.31004/basicedu.v5i6.1549

ISSN 2580-3735 (Media Cetak)

ISSN 2580-1147 (Media Online)

Jurnal Basicedu Vol 5 No 6 Tahun 2021

p-ISSN 2580-3735 e-ISSN 2580-1147 
5205 Peningkatan Kemampuan Berliterasi melalui Model Discovery Learning Berbantuan Media Pohon Literasi - Maria Ulfa, Eva Oktaviana

DOI: https://doi.org/10.31004/basicedu.v5i6.1549

\section{PENDAHULUAN}

Sudahkan kita membaca hari ini? Pertanyaan sepele namun sulit untuk dijawab. Seringkali kita beranggapan bahwa kegiatan membaca haruslah berkaitan dengan buku. Padahal sarana untuk membaca sangatlah banyak, tidak terbatas pada buku yang tercetak. Apalagi di abad ke-21 ini, sumber bacaan menjadi sangat beragam. Selain buku, kita dapat membaca melalui sumber online yang tentunya dapat diakses melalui piranti elektronik, seperti e-book, e-magazine, e-newspaper, dan lainnya.

Pada abad ke-21 kemampuan membaca adalah hal utama yang harus dimiliki oleh setiap manusia di dunia. Tuntutan di abad ini adalah peningkatan mutu dan kualitas manusia. Yang tentunya diawali oleh literatnya masyarakat. Sehingga menciptakan kemampuan membaca yang tinggi dan pemahaman dalam menghadapi masalah-masalah yang muncul dalam hidup. Membaca dapat pula dikatakan sebagai aktivitas atau proses penangkapan dan pemahaman sejumlah pesan atau informasi dalam bentuk tulisan. Dengan membaca maka kegiatan otak untuk mencerna dan memahami serta memaknai simbol-simbol. Apabila seseorang membaca dapat merangsang otak untuk melakukan olah pikir untuk memahami makna yang terkandung dalam rangkaian simbol-simbol (tulisan). Semakin sering seseorang membaca maka semakin tertantang untuk terus berpikir terhadap apa yang mereka baca (Muslimin, 2018).

Apabila kita mengukur diri sendiri sebagai masyarakat Indonesia apakah mungkin bisa menghadapi dan bertahan di abad ke-21? Bukan rahasia umum kalau masyarakat Indonesia malas membaca. Hasil Programme for International Student Assessment (PISA) tahun 2018 Indonesia berada di peringkat ke 74 dari 79 negara partisipan PISA pada kategori kemampuan membaca (Hewi \& Saleh, 2020). Selain itu, hasil PISA Indonesia pada tahun 2018 untuk kategori kemampuan membaca Indonesia di peringkat ke 74 jauh di bawah Thailand yang berada di peringkat ke 68, Malaysia berada di peringkat ke 58 sementara Singapura berada di peringkat ke 2 (Schleicher, 2019).

Hasil PISA yang menunjukan rendahnya kemampuan berliterasi berkaitan erat dengan tuntutan keterampilan membaca yang berujung pada kemampuan memahami informasi secara analitis, kritis, dan reflektif (Utami, Faizah Dewi, 2016). Dari hasil PISA tersebut patutnya menjadi referensi acuan dan evaluasi terhadap kualitas pendidikan suatu negara, khususnya Indonesia. Skor PISA yang rendah menjadikan pendidikan di Indonesia berada jauh dari level pasar global atau negara standar pendidikan yang sesuai dengan kebutuhan pasar internasional.

Mengapa rendahnya literasi di Indonesia menjadi momok yang menakutkan? Literacy is the ability to identify, understand, interpret, create, communicate and compute, using printed and written materials associated with varying contexts. Literacy involves a continuum of learning in enabling individuals to achieve their goals, to develop their knowledge and potential, and to participate fully in their community and wider society (E. Oghenekohwo \& A. Frank-Oputu, 2017). Literasi memiliki makna meluas dari waktu ke waktu. Literasi sekarang tidak hanya diartikan sebagai kemampuan menulis dan membaca, tetapi kini literasi memiliki makna dan implikasi dari keterampilan membaca dan menulis dasar ke pemerolehan dan manipulasi pengetahuan melalui teks tertulis, dari analisis metalinguistik unit gramatikal ke struktur teks lisan dan tertulis (Tadkiroatun Musfiroh dan Beniati Listyorini, 2016). Untuk menghadapi kehidupan di abad ke-21 kemampuan berliterasi sangatlah diperlukan.

Hasil PISA terutama literasi Indonesia yang rendah juga tercermin pada kemampuan membaca mahasiswa Program Studi Pendidikan Guru Sekolah Dasar (Prodi PGSD) STKIP Kusuma Negara. Sebagai upaya untuk meningkatkan kemampuan berliterasi mahasiswa STKIP Kusuma Negara atau wujud dari terciptanya Gerakan Literasi Sekolah, Prodi PGSD menjadikan literasi sebagai salah satu mata kuliah pilihan. Pembelajaran Literasi SD adalah salah satu mata kuliah pilihan yang digalakan oleh Prodi PGSD STKIP Kusuma Negara guna meningkatkan kemampuan berliteasi mahasiswa. Selain itu, mata kuliah ini juga bertujuan untuk menyiapkan pada lulusan yang akan menjadi guru SD agar mampu melaksanakan pembelajaran literasi yang baik dan tetap. 
Peneliti adalah dosen pengampu mata kuliah tersebut. Pada saat awal pembelajaran diadakan pre test untuk mengukur kemampuan berliterasi mahasiswa Prodi PGSD STKIP Kusuma Negara. Pre test yang dilakukan adalah dengan memberikan sebuah bahan bacaan untuk dibaca oleh para mahasiswa dan setelah itu terdapat soal yang berkaitan dengan isi teks dan harus dijawab. Hasil yang didapatkan adalah dari 60 mahasiswa peserta mata kuliah 75\% mendapatkan nilai di bawah KKM dan 25\% mendapatkan nilai di atas KKM. Berarti baru seperempat mahasiswa Prodi PGSD STKIP Kusuma Negara yang memiliki kemampuan dalam mencerna teks bacaan.

Tentunya hal tersebut terjadi karena beberapa faktor, yakni rata-rata mahasiswa Prodi PGSD STKIP Kusuma Negara adalah pekerja lepas. Dimana perkerjaan tersebut memungkinkan mereka jarang sekali membaca. Kedua, kondisi pandemi saat ini yang membuat mahasiswa meluangkan hampir setiap waktunya untuk berselancar dengan gawai. Yang terakhir adalah karena memang mereka jarang membaca. Membaca dilakukan apabila diperlukan saja. Apabila merujuk dari 3 penyebab rendahnya minat membaca mahasiswa di atas tidak sesuai dengan fakta, yakni proses pembelajaran daring yang masih terus berlanjut sampai saat ini menuntut kesadaran mahasiswa untuk dapat belajar secara mandiri Kegiatan belajar mandiri dilakukan dengan memanfaatkan aktivitas membaca secara efektif untuk menambah wawasan (Hakim, 2021).

Hal tersebut harus benar-benar mendapatkan perhatian yang serius. Budaya membaca pada mahasiswa haruslah dioptimalkan. Mahasiswa adalah salah satu ujung tombak untuk memperbaiki kualitas sumber daya manusia. Apabila kondisi tersebut tidak diperbaiki maka mereka tidak akan mampu bersaing sesuai tuntutan abad ke-21. Penguatan terhadap kemampuan berliterasi mahasiswa Prodi PGSD STKIP Kusuma Negara haruslah ditingkatkan. Kemampuan berliterasi membantu mahasiswa dalam memahami semua mata kuliah yang dipelajarinya. Semua mata kuliah menuntut mahasiswa untuk berpikir secara mendalam. Kemampuan literasi juga berbanding lurus dengan kemampuan daya nalar (Waskim, 2017).

Melihat kondisi yang ada pada mahasiswa maka perlu perlakuan yang berbeda dalam proses pemupukan kemampuan literasi mahasiswa. Model pembelajaran yang tepat dibutuhkan untuk mengembangkan kemampuan literasi. Kondisi pandemi covid-19 saat ini menuntut mahasiswa harus mandiri saat melaksanakan pembelajaran. Model pembelajaran yang cocok diterapkan pada kondisi pandemi covid-19 seperti ini saat ini adalah model pembelajran yang menitikberatkan pada pembelajaran secara mandiri. Model tersebut adalah discovery learning.

Model discovery learning ialah pembelajaran yang dirancang secara sistematis, agar mahasiswa mampu memperoleh pengetahuan atau konsep-konsep dengan menemukan sendiri, melalui kegiatan eksperimen atau percobaan (Hamdani, 2011). Dalam penerapan discovery learning, mahasiswa diberikan masalah yang berkaitan dengan konsep materi perkulaiahan, kemudian dosen memberi kesempatan mahasiswa menemukan konsep materi oleh mahasiswa sendiri, dan dosen berperan sebagai pembimbing.

Dalam menerapkan model discovery learning menungkinkan mahasiswa untuk mencari dan membaca berbagai macam buku atau artikel pada jurnal-jurnal tertentu. Dan untuk menstimulus tersebut mahasiswa selain penerapan model discovery learning juga dapat mengkombinasikannya dengan bantuan media pohon literasi. Dalam GLS pohon literasi adalah media yang dapat diterapkan untuk mengukur jumlah bacaan yang sudah dibaca. Semakin rimbun pohon tersebut berarti semakin banyak buku yang sudah dibaca. Untuk menjalankan model discovery learning memungkinkan mahasiswa mencari berbagai sumber bacaan. Dan semakin banyak sumber bacaan yang sudah dibaca akan tercermin pada pohon literasi yang sudah dibuatnya. Serta keluasan pemahaman terhadap pemahaman tugas yang akan diberikan akan tercermin pada rimbunnya pohon literasi yang sudah dibuat. Oleh sebab itu, penelitian ini akan mengkaji tentang "Peningkatan Kemampuan Berliterasi Melalui Model Collaborative Learning Dengan Berbantuan Media Pohon Literasi Pada Mahasiswa STKIP Kusuma Negara. 
5207 Peningkatan Kemampuan Berliterasi melalui Model Discovery Learning Berbantuan Media Pohon Literasi - Maria Ulfa, Eva Oktaviana

DOI: https://doi.org/10.31004/basicedu.v5i6.1549

\section{METODE}

Penelitian Action Research Classroom ini dilaksanakan pada Prodi PGSD, STKIP Kusuma Negara dari bulan Februari hingga Juli 2021. Subjek penelitian ini adalah mahasiswa semester VI yang mengikuti mata Kuliah Pembelajaran Literasi SD tahun ajaran 2020/2021 yang berjumlah 60 mahasiswa. Data penelitian ini meliputi penerapan model discovery learning dengan berbantuan media pohon literasi dan data hasil menulis essai. Adapun teknik yang pengumpulan data yaitu observasi, wawancara, tes, dan analisis dokumen. Untuk mengukur kemampuan mahasiswa dalam berliterasi menggunakan tes menulis essai. Tes essai yang diberikan merupakan tes yang sudah teridiri dari berbagai jenis keterampilan seperti membaca, menulis, memproses informasi, ide dan pendapat, pengambilan keputusan dan pemecahan masalah (Indriyani et al., 2019).

Teknik uji validasi data yang digunakan pada penelitian ini ada 3, yaitu triangulasi sumber data, teknik validitas isi, dan triangulasi teknik. Triangulasi sumber data dalam penelitian ini diperoleh dari mahasiswa semester 6 Prodi PGSD STKIP Kusuma Negara tahun ajaran 2020/2021. Teknik validitas isi dilihat melalui kisi-kisi pedoman wawancara mahasiswa dan rubrik penilaian tes essai. Sedangkan triangulasi teknik dalam penelitian ini meliputi observasi, wawancara, dan tes. Analisis data yang digunakan dalam penelitian adalah reduksi data, penyajian data, dan penarikan kesimpulan sesuai model analisis data menurut Miles dan Huberman dalam (Sugiyono, 2017). Adapun prosedur dari penelitian ini meliputi: (1) Perencanaan, (2) Pelaksanaan, (3) Pengamatan, dan (4) Refleksi. Kriteria keberhasilan yang digunakan dalam penelitian ini adalah penerapan model discovery learning berbantuan media pohon literasi dan peningkatan keterampilan literasi ditunjukan dengan kemampuan menulis essai $(\mathrm{KKM}=80)$ ditargetkan mencapai $80 \%$.

\section{HASIL DAN PEMBAHASAN}

Penerapan model discovery learning berbantuan media pohon literasi dalam meningkatkan kemampuan berliterasi mahasiswa semester 6 Prodi PGSD STKIP Kusuma Negara Tahun Ajaran 2021/2022 dilakukan dalam dua siklus, tiap siklus dilakukan satu kali pertemuan. Model discovery learning adalah salah satu model belajar mengajar yang didasarkan pada fenomena kontekstual. Menurut Bruner dalam (Muliati, 2021) stated that learning happens by discovering, which prioritizes reflection, thinking, experimenting, and exploring. Dengan menerapkan model dicovery learning peserta didik dituntut untuk menggunakan kemampuan berpikir tingkat tinggi, berani melakukan eksperimen, dan mengeksplorasi temuan data yang diperolehnya dan itu semua membuat peserta didik menjadi penemu akan solusi dari masalah yang dihadapinya dalam proses pembelajaran.

Penelitian ini dilakukan saat perkuliahan Pembelajaran Literasi di SD dimana peneliti bertindak sebagai dosen pengampu. Seluruh penelitian dilaksanakan secara daring melalui aplikasasi google meet (kegiatan synchronous) dan whatsapp group (kegiatan asynchronous). Di awal perkuliahan mahasiswa diberikan pre test untuk mengukur kemampuan membacanya. Pada kegiatan synchronous mahasiswa diberikan teks legenda berjudul Puteri Runduk dan secara bersama-sama membacanya selama 5 menit. Setelah 5 menit bacaan tersebut sudah tidak dapat diakses lagi oleh mahasiswa. Kemudian peneliti memberikan 10 soal isian singkat yang jawabannya terdapat pada teks yang telah dibaca oleh mahasiswa. Hasil pre test kemampuan membaca mahasiswa ditujukan sebagai berikut:

Tabel 1

Rekapitulasi Nilai Kemampuan Berliterasi Pra Tindakan

\begin{tabular}{rcc}
\hline \multirow{2}{*}{ Ketuntasan Belajar } & \multicolumn{3}{c}{ Jumlah Mahasiswa } \\
\cline { 2 - 4 } \multicolumn{1}{c}{ Tuntas } & Jumlah & Presentase \\
\hline Belum Tuntas & 15 & $25 \%$ \\
\hline Jumlah & 45 & $75 \%$ \\
\hline Nilai Maksimal & 60 & $100 \%$ \\
\hline Nilai Minimal & & 90 \\
Rata-Rata & \multicolumn{3}{c}{} \\
\hline
\end{tabular}


5208 Peningkatan Kemampuan Berliterasi melalui Model Discovery Learning Berbantuan Media Pohon Literasi - Maria Ulfa, Eva Oktaviana

DOI: https://doi.org/10.31004/basicedu.v5i6.1549

Berdasarkan tabel $1 \mathrm{di}$ atas, diketahui rata-rata kemampuan pemahaman mahasiswa terhadap isi teks bacaan adalah 53.33 dengan nilai maksimal yang diperoleh adalah 90 dan nilai terendah adalah 0 serta hanya $25 \%$ mahasiswa yang mendapatkan nilai di atas KKM yang telah ditentukan oleh dosen. Rendahnya kemampuan membaca mahasiswa disebabkan oleh bebrapa faktor, yakni tidak adanya kegemaran membaca dan tidak adanya bahan bacaan di rumah mahasiswa. Dari 60 mahasiswa diketahui hanya 18,30\% yang gemar membaca atau setiap harinya meluangkan waktu untuk membaca artikel pada internet atau buku cetak. Dan $71,70 \%$ mahasiswa tidak gemar membaca karena tidak memiliki waktu untuk membaca dan tidak

\section{Kegemaran Membaca}

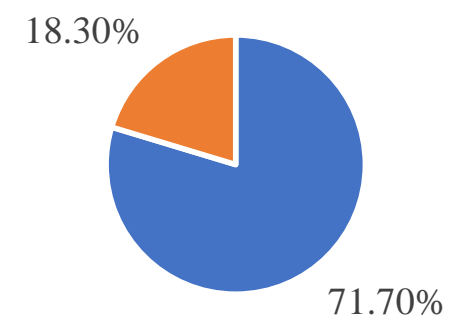

- Tidak Gemar Membaca Gemar Membaca

Grafik 1. Kegemaran Membaca Mahasiswa

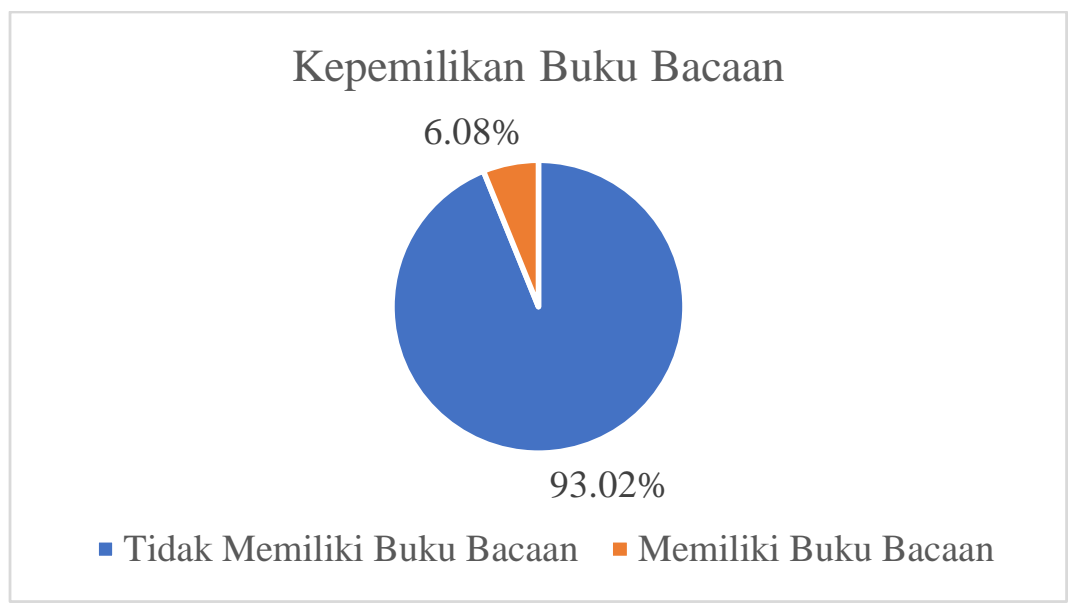

\section{Grafik 2. Kepemilikan Bahan Bacaan}

Kemampuan berliterasi diawali dari kebiasaan membaca. Melalui kegiatan membaca dapat mengembangkan kemampuan seseorang dalam berpikir secara kritis (Puspasari \& Dafit, 2021). Apabila sudah memiliki dan membiasakan diri dalam membaca, maka akan muncul kemampuan berliterasi. Kemampuan berliterasi bukan hanya diperlukan untuk mengikuti mata kuliah Pembelajaran Litersi di SD seperti yang dilakukan dalam penelitian ini. Untuk dapat memiliki kemampuan dalam berliterasi diawali dari adanya kesadaran berliterasi sangat mendukung keberhasilan seseorang dalam menangani berbagai persoalan. Melalui kemampuan literasi, seseorang tidak saja memperoleh ilmu pengetahuan tetapi juga bisa mendokumentasikan sepenggal pengalaman yang menjadi rujukan di masa yang akan datang (Lifia Yola Putri Febrianti dan Oviolanda Irianto, 2017).

Tabel 2

Rekapitulasi Nilai Kemampuan Berliterasi Siklus I dan II

\begin{tabular}{lcc}
\hline Ketuntasan Belajar & \multicolumn{2}{c}{ Presentase Siklus (\%) } \\
\cline { 2 - 3 } & I & II \\
\hline Tuntas & 56,67 & 83,33 \\
\hline
\end{tabular}


DOI: https://doi.org/10.31004/basicedu.v5i6.1549

\begin{tabular}{|c|c|c|}
\hline Belum Tuntas & 43,33 & 16.67 \\
\hline Nilai Maksimal & 95 & 100 \\
\hline Nilai Minimal & 40 & 65 \\
\hline Rata-Rata & 72,42 & 85 \\
\hline
\end{tabular}

Berdasarkan tabel 2 di atas, hasil penelitian penerapan model discovery learning berbantuan media pohon literasi untuk meningkatkan kemampuan berliterasi mahasiswa Prodi PGSD STKIP Kusuma Negara berhenti pada siklus II. Hal ini disebabkan oleh kriteria keberhasilan mengajar di siklus II sudah mencapai 83,33\% sedangkan di siklus I sebesar 56,67\%. Nilai maksimal di siklus I adalah 95 dan siklus II 100. Serta rata-rata nilai kemampuan berliterasi mahasiswa pada siklus I adalah 72,42 dan 85 di siklus II.

Berdasarkan data pre test peneliti melakukan perencanaan untuk melakukan perubahan pola pembelajaran agar kemampuan mahasiswa dalam mengerjakan pre test tidak sama dengan kemampuan akhir yang diperoleh pada mata kuliah ini. Setelah itu, peneliti menentukan model pembelajaran yang tepat agar mahasiswa mampu termotivasi agar mau membaca dan mampu memahami bacaan yang telah dibacanya. Lalu peneliti memilih model pembelajaran discovery learning untuk mahasiswa agar mampu berpikir kritis, berani melakukan eksperimen, dan mengeksplorasi temuan data yang diperolehnya dari sumber bacaan yang telah dibacanya. Selain itu, paradigma terkait membaca haruslah bacaan cetak perlu diubah. Membaca sangatlah luas bukan hanya dari buku cetak saja tetapi membaca dapat dilakukan dengan gawai mereka.

Sedangkan kegemaran dan waktu membaca yang tidak dimiliki mahasiswa perlu diberikan solusi. Untuk mengatasi hal tersebut peneliti menggunakan bantuan media pohon literasi. Media pohon literasi yang dimaksud adalah pembiasaan membaca bagi para mahasiswa. Mahasiswa diminta untuk membuat sebuah pohon dengan daun terpisah. Daun dianalogikan dengan jumlah bacaan yang dibaca mahasiswa. Mahasiswa diminta untuk membaca minimal 1 artikel yang ada pada media daring. Setelah mahasiswa membaca maka berhak memberikan satu daun pada pohon literasi yang dibuat. Apabila mahasiswa membaca begitu banyak bahan bacaan, maka akan semakin rimbun pohon yang dimilikinya. Semakin rimbun pohon literasi mahasiswa, maka semakin banyak pengetahun yang mereka peroleh.

Dengan analogi ini, diharapkan semakin banyak sumber bacaan yang dibaca oleh mahasiswa maka akan membentuk mahasiswa menjadi masyarakat literat. Sebab Kemampuan membaca merupakan saah satu ciri masyarakat literat. Secara sederhana, masyarakat literat adalah masyarakat yang memiliki kemampuan membaca dan menulis atau melek aksara. Literacy sebagai mampu untuk membaca dan menulis (able to read and write), sedangkan orang yang mampu keduanya disebut literat (Wahyuni, 2015).

Dalam mengatasi permasalahan rendahnya kemampuan berliterasi mahasiswa, maka penerapan model discovery learning menjadi sangat penting. Adapun sintak penerapan model discovery learning yang diterapkan pada penelitian ini adalah stimulation, problem statement, data collection, data processing, verification, and generalization (Kemendikbud, 2013). Adapun keenam langkah penerapan model discovery learning yang diterapkan pada penelitian ini adalah sebagai berikut:

Tabel 3

Sintak Penerapan Model Discovery Learning

Tahap

Stimulation

Problem Statement masala dicari kebenarannya.

Tahap ini adalah eksplorasi terhadap berbagai sumber-sumber bacaan yang berkaitan dengan identifikasi masalah yang telah ditentukan oleh mahasiswa. Tahap ini pula dilakukan untuk menjawab identifikasi dan hipotesis yang sudah dirumuskan oleh 
mahasiswa. Pengumpulan berbagai sumber pendukung untuk menjawab dan menguji hipotesis sangatlah diperlukan.

Data Processing Berbagai informasi yang diperoleh mahasiswa direduksi, diolah, diklasifikasikan, ditabulasi, bahkan dihitung dengan berbagai rumus tertentu untuk ditafsirkan pada tingkat kepercayaan tertentu.

Verification Tahap ini dilakukan untuk memeriksa secara teliti dan untuk mengabsahkan data yang diperoleh, dirumuskan, dan yang akan disajikan. Pemahaman-pemahaman baru akan sebuah alternatif pemecahan masalah menjadi kunci pada tahap ini.

Generalization Menarik sebuah kesimpulan adalah proses terakhir dari tahapan ini. Penarikan esimpulan dijadikan prinsip yang sifatnya umum untuk masalah yang serupa.

Memalui model discovery learning Begitu pula dengan penelitian ini peningkatan kemampuan berliterasi mahasiswa melalui model discovery learning berbantuan media pohon literasi terlihat jelas pada hasil akhir dalam menyelesaikan tes essai. Dari aspek membaca dan menulis, mahasiswa menjadi luas pengetahuan dan pemahamannya. Sehingga akan semakin bijak pula untuk mencari alternatif dalam menyelesaikan permasalahan yang diberikan. Tetapi untuk dapat melakukan hal tersebut, bacaan yang dibaca pun haruslah beragam. Dengan keberagaman bacaan maka dapat menjadikan membaca sebagai suatu budaya. Sebagai suatu budaya, membaca hadir karena adanya kebiasaan. Kebiasaan membaca ada jika ada rencana membaca secara rutin dan rutinitas dalam membaca (Suarni et al., 2019).

Perlu ditegaskan peningkatan kemampuan berliterasi bukan hanya diukur dari kemampuan membaca saja. Kemampuan berliterasi diuji dengan mengukur aspek memahami, menggunakan, dan merefleksikan hasil membaca dalam bentuk tulisan (Indriyani, Vivi, Atmazaki, 2019). Setelah itu, dalam kemampuan berliterasi terdapat model Contruction-Integration untuk menjelaskan proses memahami teks. Konsep ini menguraikan bahwa pada tingkatan pertama Construction, pembaca perlu memahami teks di tingkat kata dan kalimat untuk menemukan ide atau gagasan di tiap kalimat. Selanjutnya, proses selanjutnya adalah pembaca perlu memahami di tingkat teks keseluruhan (wacana). Tahapan terakhir, Integration, pembaca perlu menghubungkan dan mengintegrasikan isi teks dengan pengetahuan di luar teks (knowledge of the world) sehingga pemahaman terhadap teks menjadi lebih komprehensif dan realistis (Ulla et al., 2020).

Dengan menerapkan model discovery learning dalam pembelajaran akan membuat mahasiswa semakin berpikir kritis. Hal tersebut sesuai dengan karakteristik dari model discovery learning. Model discovery learning secara nyata membuat peserta didik terlihat bersemangat dan aktif saat proses pembelajaran dimana peserta didik dituntut untuk menyelidiki, menemukan sendiri jawaban atas permasalahan yang diberikan oleh pendidik, dengan demikian membuat peserta didik untuk menuangkan ide dan pendapatnya masing- masing (Hasnan et al., 2020). Tentunya di abad 21 ini, kemampuan literasi tidak hanya sekadar membaca dan menulis, namun melibatkan keterampilan berpikir yang membuat mereka literate dalam belajar (Septiani, Devi Ayu, Eka Junaidi, 2019).

Oleh sebab itu, kemapuan berliterasi haruslah dimiliki setiap mahasiswa. Dengan kemampuan berliterasi mahasiswa menjadikan pengetahuan dan pemahakan yang semakin luas. Kemampuan berliterasi diperlukan dalam setiap mata kuliah. Kedalaman pengetahuan dan pemahaman terkait dengan materi perkuliahan akan membantu mahasiswa dalam memecahkan masalah dalam kehidupan sehari-hari.

\section{KESIMPULAN}

Penelitian ini bertujuna untuk meningkatkan kemampuan berlitersi melalui model discovery learning berbantuan media pohon literasi. Penerapan model pembelajaran discovery learning berbantuan media pohon literasi terbukti mampu meningkatkan kemampuan mahasiswa Prodi PGSD, STKIP Kusuma Negara. Hal ini terlihat dari kriteria keberhasilan di di siklus I sebesar 56,67\%. Nilai maksimal di siklus I adalah 95. Dan di siklus II kriteris keberhasilan mencapai 83,33\% sedangkan nilai terbesar adalah 100. 
5211 Peningkatan Kemampuan Berliterasi melalui Model Discovery Learning Berbantuan Media Pohon Literasi - Maria Ulfa, Eva Oktaviana

DOI: https://doi.org/10.31004/basicedu.v5i6.1549

Dalam proses penelitian mengharuskan mahasiswa membaca banyak sumber bacaan. Dapat dilihat dari rimbunnya pohon literasi yang mereka buat selama satu semester. Banyaknya sumber bacaan yang telah membaca tentunya dapat membuka wawasan mahasiswa dalam menghadapi berbagai permasalahan. Dengan stimulus yang diberikan kepada masiswa tentang berbagai masalah yang ada dapat menjadikan mahasiswa lebih kritis dan mampu mencari solusi akan masalah-masalah yang dihadapi. Dan inilah yang diperlukan untuk menjadi mahasiswa dan manusia yang mampu beradaptasi di abad ke-21 ini.

\section{DAFTAR PUSTAKA}

E. Oghenekohwo, J., \& A. Frank-Oputu, E. (2017). Literacy Education and Sustainable Development in Developing Societies. International Journal of Education and Literacy Studies, 5(2), 126. https://doi.org/10.7575/aiac.ijels.v.5n.2p.126

Hakim, M. N. (2021). Studi Tingkat Literasi Membaca Mahasiswa Selama Pembelajaran Daring. Bahtera Indonesia; Jurnal Penelitian Bahasa Dan Sastra Indonesia, 6(1), 77-87. https://doi.org/10.31943/bi.v6i1.112

Hamdani. (2011). Strategi Belajar Mengajar. CV Pustaka Setia.

Hasnan, S. M., Rusdinal, R., \& Fitria, Y. (2020). Pengaruh Penggunaan Model Discovery Learning Dan Motivasi Terhadap Kemampuan Berpikir Kritis Peserta Didik Sekolah Dasar. Jurnal Basicedu, 4(2), 239249. https://doi.org/10.31004/basicedu.v4i2.318

Hewi, L., \& Saleh, M. (2020). Penguatan Peran Lembaga PAUD untuk Program International Student Assesment (PISA). Jurnal Program Studi Pendidikan Guru PAUD STKIP Siliwangi Bandung, 6(2), 63 70. http://www.e-journal.stkipsiliwangi.ac.id/index.php/tunas-siliwangi/article/view/2081

Indriyani, Vivi, Atmazaki, dan S. R. (2019). Literasi Baca Tulis Dan Inovasi Kurikulum Bahasa. Kembara: Jurnal Keilmuan Bahasa, Sastra, Dan Pengajarannya, 5(1). https://doi.org/https://Doi.Org/10.22219/Kembara.V5i1.7842

Indriyani, V., Zaim, M., Atmazaki, A., \& Ramadhan, S. (2019). Literasi Baca Tulis Dan Inovasi Kurikulum Bahasa. KEMBARA: Jurnal Keilmuan Bahasa, Sastra, Dan Pengajarannya, 5(1), 108. https://doi.org/10.22219/kembara.vol5.no1.108-118

Kemendikbud. (2013). Badan Pengembangan Sumber Daya Manusia Pendidikan Dan Kebudayaan Dan Penjaminan Mutu Pendidikan Tentang Model Pembelajaran Penemuan (Discovery Learning). Kementerian Pendidikan Nasional.

Lifia Yola Putri Febrianti dan Oviolanda Irianto. (2017). Pentingnya Penguasaan Literasi bagi Generasi Muda dalam Menghadapi Mea. 640-647. http://jurnal.unissula.ac.id/index.php/ELIC/article/view/1282

Muliati, et. all. (2021). Current Research In ELT. CV. Prima Putra Pratama.

Muslimin. (2018). Penumbuhan Budaya Literasi Melalui Peningkatan Minat Baca Masyarakat desa. Cakrawala Pendidikan, 37(1), 107-118.

Puspasari, I., \& Dafit, F. (2021). Implementasi Gerakan Literasi Sekolah di Sekolah Dasar. Jurnal Basicedu, 5(3), 1390-1400.

Schleicher, A. (2019). PISA 2018. OECD.

Septiani, Devi Ayu, Eka Junaidi, A. A. P. (2019). Hubungan Antara Keterampilan Berpikir Kritis Dan Kemampuan Literasi Sains Pada Mahasiswa Pendidikan Kimia Di Universitas Mataram. Prosiding Seminar Nasional FKIP Universitas Mataram, 1, 11-12. https://jurnalfkip.unram.ac.id/index.php/PSN/article/view/1579/pdf

Suarni, N., Taufina, T., \& Zikri, A. (2019). Literasi Membaca Meningkatkan Karakter Positif Siswa Sekolah Dasar. Jurnal Basicedu, 3(4), 1014-1021. https://doi.org/10.31004/basicedu.v3i4.215

Sugiyono. (2017). Metode Penelitian Kuantitatif, Kualitatif, dan R\&D. CV Alfa Beta. 
5212 Peningkatan Kemampuan Berliterasi melalui Model Discovery Learning Berbantuan Media Pohon Literasi - Maria Ulfa, Eva Oktaviana

DOI: https://doi.org/10.31004/basicedu.v5i6.1549

Tadkiroatun Musfiroh dan Beniati Listyorini. (2016). Konstruk Kompetensi Literasi untuk Siswa Sekolah Dasar. LITERA, the International Journal of Linguistics, Literature, and Their Teaching, Volume 15. https://journal.uny.ac.id/index.php/litera/article/view/9751/pdf

Ulla, N., Sahiruddin, \& Khasanah, I. (2020). Sosial budaya yang Berpengaruh Terhadap Minat Membaca Mahasiswa Unmer Malang Kondisi minat baca bangsa Indonesia memang cukup meprihatinkan . Berdasarkan studi " Most Littered Nation In the World " yang dilakukan oleh Central Connecticut State Univesity p. Diglossia, 11(2), 41-54.

Utami, Faizah Dewi, D. (2016). Panduan Gerakan Literasi Sekolah Di Sekolah Dasar. Direktorat Jenderal Pendidikan Dasar dan Menengah Kementerian Pendidikan dan Kebudayaan.

Wahyuni, S. (2015). Menumbuhkembangkan Minat Baca Menuju Masyarakat Literat. Diksi, 16(2), 179-189. https://doi.org/10.21831/diksi.v16i2.6617

Waskim. (2017). Optimalisasi Budaya Literasi di Kalangan Mahasiswa. Jurnal Pendidikan, 70-73. https://d1wqtxts1 xzle7.cloudfront.net/61047240/Optimalisasi_Budaya_Literasi_di_Kalangan20191028 51472-12jrpwr-with-cover-page-v2.pdf?Expires=1632742196\&Signature=NYUoEkkAZVYJpn8tzyJBi0NZVXw8gE3lnclfij9xMitmboMuK8V3o2N31CAED1dW4moEwYU7mkLGwZlg2yAZjQPUZjVy 